\title{
"CORPUS JURIS" - ETT FRESTANDE ELLER ETT FRÄMMANDE FÖRSLAG TILL EN ENHETLIG EUROPEISK RÄTTSSFÄR?
}

\author{
Av Per Ole Träskman
}

\section{NORDISK EU-SKEPTICISM}

Det 11. Nordiska kriminalistmötet arrangerades i Köpenhamn 1994. Ett av de teman som diskuterades var "Förhållandet mellan EU-straffrätten och den nationella straffrätten. ${ }^{1}$ Huvudinledaren, professor Vagn Greve, konstaterade bl a att det redan nu finns en viss rättsgemenskap mellan EU-staterna genom att avgränsningen för det kriminaliserade området i stor utsträckning är det samma. Detta är till en del en följd av att EU redan har harmoniserat stora områden av straffiätten genom traktaten, förordningar, direktiv etc. Till en del är detta också en följd av att medlemstaterna har en gemensam kulturell bakgrund; det som kan kallas kärnstraffrätten (de traditionella brotten som mord, dråp, stöld etc.) är rimligt identiskt (en närmare granskning visar emellertid att vissa, t o m betydande, skillnader finns). Rättsgemenskapen är därtill en följd av att andra former för internationellt samarbete, framför allt inom FN och Europarådet, har lett till en harmonisering.

Då det gäller de allmänna förutsättningarna för straffansvar finns det emellertid stora olikheter mellan EU-staterna. Detta gäller t ex bestämmelserna om brottsförsök, delaktighet i brott, personlig skuld (alltså dolus och culpa), bestraffning av brott begångna inom eller av juridiska personer och andra kollektiva enheter etc. Stora olikheter finns det också då det gäller utformningen av sanktionerna, samt beträffande bestämmelserna om utmätning av straff. På straffprocessens område är olikheterna mellan medlemsstaterna i många avseenden mycket stora.

Då det gäller framtiden konstaterade Vagn Greve att det finns tre huvudmodeller för samarbetet:

(a) Straffrätten kan också i framtiden överlämnas till medlemsstaterna. Straffrätten förblir $\mathrm{m}$ a o en $\mathrm{i}$ huvudsak nationell angelägenhet. För att undgå alltför stora olikheter mellan medlemsstaterna förutsätts det dock en viss assimilation, en viss harmonisering, samt naturligtvis samarbete.

(b) Straffrätten överlämnas till EU, d v s straffrätten förenhetligas.

(c) Straffrätten uppdelas i en nationell och i en gemensam straffrätt. Varje medlemsstat har sin egen strafflag och unionen har en som gäller gemensamt för alla.

Vagn Greves konklusion var att det av flera skilda skäl inte är förnuftigt att i detta skede gå in för modell $b$, speciellt inte då det gäller den del av den centrala straffrätten som är intimt förbunden med etiska värderingar (alltså de brott som ofta betecknas som mala in se). Då det gäller den etiskt mer indifferen ta delen av straffiätten (mala prohibita), finns det goda skäl för att närma medlemsstaternas lösningar till varandra, $\mathrm{m}$ a o att fortsätta en assimilering och en harmonisering med tanke på ett lättare samarbete. Då det gäller 
de allmänna förutsättningarna för straffansvar och sanktionerna är skillnaderna mellan medlemsstaterna ännu så stora att det inte finns en tillräcklig grund för en effektiv harmonisering. Vagn Greves eget förslag var att man skulle börja med att identifiera de etiskt neutrala och gemensamma områdena för att utarbeta en "model penal code" för dessa delområden, och sedan arbeta för en nationell accept av de lösningar som man valt i denna modellstrafflag.

Det är mycket sannolikt att Vagn Greve i sitt inlägg gav uttryck för vad som kan kallas den förhärskande uppfattningen bland de nordiska kriminalvetenskapliga forskarna och de jurister som är praktiskt verksamma inom straffrätt, straffprocess och kriminalvård. Vagn Greve gav inte $\mathrm{i}$ inlägget något bud på om straffprocessrätten inom EU skulle förenhetligas. Det sannolika är emellertid att majoriteten av de sakkunniga i Norden skulle ha avrått från denna tanke.

\section{2. "CORPUS JURIS"}

År 1995 lancerade General Directorate XX of the European Commission ett projekt" The European Legal Area Project". Projektarbetet genomfördes av en grupp experter under 6 månader och resulterade i ett förslag kallat Corpus Juris. ${ }^{2}$ Förslaget innehåller vissa straffbestämmelser för att skydda EU:s finansiella intressen inklusive vissa processbestämmelser. Förslaget innebär explicit ett förenhetligande, en "unification", av en del av straffrätten och straffprocessrätten inom EU. ${ }^{3}$ Det utgör således en första del av en gemensam straffrätt vid sidan av de existerande nationella straffrättssystemen (Jfr Vagn Greves modell 3 ovan). Samtidigt har man redan nu -bl a från vissa personers sida som är knutna till kommissionen och till EU-parlamentet- betecknat förslaget som ett "embryo till en gemensam unionsstraffrätt" (Jfr Vagn Greves modell 2 ovan).

Förslaget har motiverats av att alla åtgärder som hittills har vidtagits för att förbättra skyddet av EUs finanisiella intressen har visat sig vara otillräckliga. Assimilation, samarbete och harmonisering är inte nog för att skapa ett tillräckligt skydd. Vad som behövs är ett förenhetligande $!^{4}$

Åtgärderna för att lancera och snabbt realisera Corpus Juris ståri en mycket klar konflikt med den rekommendation som Vagn Greve formulerade vid kriminalistmötet 1994. Då Vagn Greves rekommendation kan sägas ge ett uttryck för vad som har varit en gemensam nordisk inställning, är det viktigt att se på om situationen nu har förändrats. Min avsikt med denna artikel är att granska vissa av förslagen i Corpus Juris och konfrontera dem med de lösningar som man hittills har valt i de nordiska länderna. ${ }^{5}$

\section{UTGÅNGSPUNKTEN: "NÅGOT MÅSTE GÖRAS"}

Bakgrunden till Corpus Juris-förslaget är väldigt bekant för envar som befattat sig med kriminalpolitik. Vi befinner oss i verkligheten $\mathrm{i}$ en alltför vanlig situation då det gäller kriminalpolitiskt beslutsfattande. Det konstateras att brottsligheten, eller en viss typ av brottslighet, har antagit sådana proportioner att man menar att något måste göras. Frågan är vad?

I detta fall gäller det brottsligheten som skadar EUs finansiella intressen. Man har fastslagit att brottsligheten som direkt eller indirekt riktas mot EUs finansiella intressen 
är omfattande och att den årligen leder till mycket omfattande skador. Brottsligheten är komplex och den är därtill "revealing an impressive level of organisation", it remain largely hidden, and it is international or transnational." ${ }^{\prime 6}$

För enkelhetens skull accepterar jag detta som grund för den fortsatta analysen, också om man skulle önska bättre empiriska data om denna brottslighet. Det är trots allt förvånande hur litet man, $t$ ex från kommissionens sida, har satsat på seriös, oavhängig forskning om den ekonomiska brottsligheten inom EU.?

Hur brukar ett åtgärdsprogram i en motsvarande situation se ut? På vilka nivåer överväger man i allmänhet att sätta in ökade åtgärder: ${ }^{8}$

(a) Den första nivån: De rent preventiva åtgärderna, d v s alla de åtgärder som syftar till att brott inte alls begås. Det kan handla om rent tekniska (mekaniska) lösningar för att förhindra brott. Det kan också vara kampanjer för att påverka människornas attityder och därigenom deras beteende. Det kan vara åtgärder som genom ändring av de lagbestämmelser som inte är straffrättsliga gör det svårare att begå brott. Åtgärderna innebär i dag framför allt en fokusering på det som kallas situationell brottsprevention.

(b) Den andra nivån: Åtgärder som syftar till att förbättra kontrollen över de brott som trots de preventiva åtgärderna begås. Avsikten med dessa åtgärder är attöka sannolikheten för brottsupptäckt. Dessa åtgärder innebär ofta att man ger ökade resurser åt polisen och andra brottskontrollerande myndigheter. Resurserna kan vara ekonomiska eller bestå i ökade lagliga befogenheter .

(c) Den tredje nivån: Åtgärder som syftar till att underlätta rättegången. Avsikten med dem är att öka sannolikheten för att en brottsling blir bestraffad. Under den senaste tiden har dessa åtgärder ofta bestått $i$ att avskaffa sådana internationella hinder som följer av gränserna mellan staterna, $\mathrm{d} v \mathrm{~s}$ i ett ökat samarbete då det gäller internationell rättshjälp, mer omfattande straffrättslig jurisdiktion etc.

(d) Den fjärde nivån omfattar de åtgärder som innebär en straffskärpning eller en skärpning av andra straffrättsliga sanktioner. Fråga kan vara om nya strängare straff, om en höjning av straffskalan för vissa brott, om en utvidgning av det kriminaliserade området genom nya straffbestämmelser etc.

Den nordiska kriminalpolitiken brukar betecknas som rationell, kostnadsnyttomedveten och human. Straff skall användas med stor försiktighet. Denna nordiska förnuftiga försiktighet har jag i ett annat sammanhang beskrivit på följande sätt: ${ }^{9}$

\begin{abstract}
"Control by means of punishment should be the last resort("ultima ratio"). All the criminal policy measures are to be rational, and at the same time the need for caution in the use of the criminal justice system is emphazied. It is better to work purposefully against the expansion of the penal system than in favour of such an expansion. It is also better to have the wisdom of prevention in mind, and always choose solutions which imply an effective crime prevention before solutions which focus on the punishment of allready committed crimes."
\end{abstract}

Corpus Juris projektet är ett projekt som framför allt gäller nivåerna tre och fyra ovan. I ett nordiskt kriminalpolitiskt perspektiv är det mycket förvånande att nivå ett, alltså den 
som gäller de rent preventiva åtgärderna, helt har förbigåtts. Projektet initierades uppenbarligen från första början på ett sådant sätt att alla åtgärder som kunde innebära en effektiv situationell kriminalprevention aldrig inkluderades i projektets beslutsprogram.

Detta kan inte betecknas som rationellt beslutsfattande. Det är ju uppenbart att den brottslighet som skadar EUs ekonomiska intressen framför allt är en följd av vissa strukturella problem inom EU, och att den kunde bekämpas betydligt bättre och effektivare genom ändrade strukturer inom EUän genom en ändring av medlemsstaternas straffrättsliga system. Vagn Greve har beskrivit detta på ett mycket träffande sätt: ${ }^{10}$

"Til trods for, at EU officielt hylder de fri markedsmekanismer, er store dele af systemet ren planøkonomi. Det er i sig selv vanskeligt at administrere. Når det skal ske inden for en blandningsøkonomi, bliver situationen nœrmest umulig. Og det gœelder isœr, når de indviklede tilskudsregler er lavet uden nogen form for hensyntagen til kontrolmuligheder. F. eks. afhœnger tilskudene til fåreavlere af, hvor højt oppe i bjergene, fårene grœsser; men fårene går jo ned i dalen og op på bjerget uafladeligt."

\section{GRUNDDRAGEN AV CORPUS JURIS OCH DESS SJU "PRINCIPER"}

Corpus Juris-förslaget utgörs av "a set of penal rules, which constitute a kind of corpus juris, limited to the penal protection of the financial interests of the European Union, designed to ensure, in a largely unified European legal area, a fairer, simpler and more

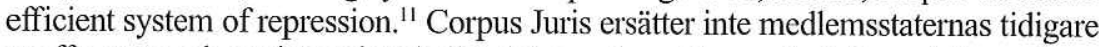
straffsystem och upphäver inte heller delar av dem. Corpus Juris kompletterar dessa system och innebär därför totalt sett en utvidgning av det straffrättsliga kontrollsystemet. Redan detta kan sägas stå i strid mot en av grundtankarna för en förnuftig kriminalpolitik: Det är ju viktigare och riktigare att arbeta för en begränsning av den straffrättsliga kontrollen än att arbeta för en utvidgning av den straffrättsliga repressionen. ${ }^{12}$

Redan dessa två första invändningar mot Corpus Juris-förslaget, d v s att förslaget ligger helt vid sidan om en brottsbekämpning som primärt bygger på en situationell, faktisk brottsprevention och att förslaget innebär en utvidgning av det straffrättsliga kontrollsystemet, är fundamentala. Invändningarna är av en sådan art att de, oberoende av förslagets närmare innehåll, skapar starka tvivel om hela projektets berättigande.

Corpus Juris-förslaget bygger på sammanlagt sju principer:

(a) legalitetsprincipen ("the legal basis of crimes and penalties");

(b) skuldprincipen ("fault as the basis for criminal liability");

(c) proportionalitetsprincipen ("proportionality of the penalty to the seriousness of the offence");

(d) principen om europeisk territorialitet ("principle of European territoriality");

(e) principen om judiciell kontroll ("principle of judicial control");

(f) principen om kontradiktoriskt förfarande ("the "truly European principle" of a procedure under which all sides are heard");

(g) principen om subsidiär tillämpning av nationell rätt ("the principle of the subsidiary application of national law"). 
De tre första principerna utgör grunden för Corpus Juris' straffrättsliga del. Dessa principer kan sägas vara väl etablerade också i ett nordiskt sammanhang. Den straffrättsliga legalitetsprincipen utgör utan tvekan den mest centrala principen inom straffrätten, och det skulle vara helt otänkbart att bygga upp ett europeiskt straffrättssystem utan att ta hänsyn till legalitetsprincipens krav. ${ }^{13}$ Straffrättsligt ansvar förutsätter alltid en form av skuld, och att bestraffa personer för brott som inte kan tillräknas dem som uppsåtliga eller oaktsamma skulle strida både mot allmänt accepterade principer för straffansvar och det allmänna rättsmedvetandet. ${ }^{14}$ Att straffet och de andra straffrättsliga sanktionerna för ett brott skall svara mot gärningens skadlighet och farlighet samt mot den skuld som gärningsmannen har visat i gärningen är i dag den grundläggande regeln för straffmätning i alla nordiska länder. ${ }^{15}$

Vid en första granskning förefaller det således som om det inte ur ett nordiskt perspektiv skulle finnas särskilt mycket kontroversiellt i de första 17 artiklarna i Corpus Jurisförslaget. En närmare analys av förslaget ändrar inte särskilt mycket på denna bedömning. Förslaget innehåller visserligen flera sådana bestämmelser som inte finns från tidigare i de nordiska länderna, eller åtminstone inte i dem alla i den form som föreslås. Som exempel kan nämnas att det finns ett visst straffrättsligt ansvar för juridiska personer och vissa andra sammanslutningar i alla tre nordiska EU-länder, alltså Danmark, Finland och Sverige, men att detta ansvar har utformats på mycket olika sätt och i olika utsträckning. ${ }^{16}$ Den bestämmelse som föreslås i Corpus Juris artikel $14^{17}$ skulle innebära en ändring av rättsläget $i$ alla dessa tre länder, men ändringen skulle knappast vara större än att den kunde genomföras utan allvarliga principiella invändningar.

Det samma kan i stort sägas gälla för de åtta straffbestämmelser som utgör kärnan i Corpus Juris' materiella del. De gärningar som föreslås bli kriminaliserade ${ }^{18}$ är redan nu kriminaliserade i stor utsträckning i de gällande nordiska strafflagarna, och en ytterligare kriminalisering kan förmodligen genomföras utan alltför stora avvikelser från den straffrättsliga traditionen i dessa länder:

\section{KRITIK MOT CORPUS JURIS' STRAFFRÄTTSLIGA BESTÄMMELSER}

Också den straffrättsliga delen av Corpus Juris-förslaget lämnar emellertid utrymme för vissa frågor och vissa reservationer. Det är knappast någon överraskning (se Vagn Greves bedömning ovan i avsnitt 1) att dessa gäller de allmänna grunderna för straffrättsligt ansvar och sanktionssystemet. Detär uppenbart att Corpus Juris-förslaget inte löser alla problem som gäller de allmänna förutsättningarna för straffrättsligt ansvar och att förslaget därför inte utgör ett förenhetligande av straffrätten inom EU, eller ens ett heltäckande bidrag till en harmonisering. Förslaget innehåller t ex inte någon bestämmelse om försök. Detta innebär att alla de olikheter som finns i detta avseende, också mellan de nordiska länderna, ${ }^{19}$ förblir bestående. Förslaget innehåller inte heller någon bestämmelse om hur uppsåt definieras och hur gränsen mellan uppsåt och oaktsamhet skall fastställas. Detta innebär att förslaget inte anvisar någon som helst lösning på de problem som framför allt finns ifråga om dolus eventualis. ${ }^{20}$

Mina reservationer mot förslaget gäller emellertid framför allt bestämmelserna om straff, straffnivå och straffimätning. 
Bland de straff som föreslås i artikel 9 finns bla offentliggörande av domen (publication of the conviction). Denna påföljd, som närmast kan betecknas som en påföljd som innebär ett målmedvetet berövande av heder och ära, är nästan helt okänd i en nordisk miljö (undantag utgör den förpliktelse som kan påläggas den som dömts för ärekränkning att i vissa fall publicera domen, eller bekosta en publicering av den, se t ex den danska strafflagen, strfl § 273).

Med beaktande av de grundläggande principerna för vilka krav som en straffrättslig påföljd måste uppfylla för att kunna godkännasär sanktionen olämplig som straffrättslig påföljd. Jag kan här hänvisa till den finska straffrättskommittén som bl a utredde möjligheterna att ta i bruk nya påföljder för brott. ${ }^{21}$

Kommittén uttalade sig härvid bl a om olika slag av "skamstraff" och fördömde dem med följande motivering:
"Likställighetsprincipen motiverar en avvisande inställning till olika slag av skamstraff. Jämfört med förmögenhets- och frihetsstraffär de svårare att avpassa till gärningsmannens skuld. Utspridande av gärningsmannens namn $\mathrm{i}$ offentligheten kunde utlösa tilläggspåföljder eller -följder; i vissa fall kunde uttryckligen den omständigheten, att vederbörande offentligt stämplas som brottsling, slutgiltigt leda in vederbörande på brottets bana. Ett flertal varierande och slumpmässiga faktorer som ansluter sig till informationsgången och andra omständigheter ställer i praktiken hinder i vägen för att den påföljdshelhet som uppkommer skulle överensstämma med likställighetsprincipen.”

En annan påföljd som endast med betydande svårigheter kan förenas med de rättsliga grundkoncept som accepterats i Norden är övervakning (legal supervision) då det gäller organisationer. En färdig modell för övervakning av organisationer som en påföljd för brott saknas, och det är också oklart vilken kriminalpolitisk roll denna typ av kontroll skall spela (en punitiv, en preventiv eller en stödjande). ${ }^{22}$ Det kan t ex finnas väldigt olika meningar om vilka befogenheter som de myndigheter skall fă som genomför kontrollen, ${ }^{23}$ då det gäller att ingripa mot beslut och förfaranden som de ogillar, och hur (det ekonomiska) ansvaret mellan å ena sidan den övervakande myndigheten och den övervakade organisationens egna organ skall fördelas? ${ }^{24}$

Också bestämmelsen om förbud mot att inneha viss typ av funktion i framtiden (ban from Community and national public office) för en person som fällts för korruption, missbruk av behörighet, trolöshet mot huvudman eller brott mot tystnadsplikt (corruption, abuse of office, misappropriation of funds, disclosure of secrets pertaining one's office) kan diskuteras. Samma typ av påföljder finns visserligen sedan tidigare i de nordiska länderna, ${ }^{25}$ men användningen av dem har i praktiken medfört sådana problem som lett till kritik.

Corpus Juris' bestämmelse om straffinivån finns i artikel $9 .{ }^{26}$ Bestämmelsen om straffskalorna för brotten i artiklarna 1 till 8 är mycket schematisk. Den uppfyller knappast de krav som måste ställas på den ordinala proportionaliteten inom straffsystemet, alltså på en gradering av brotten utgående från deras inbördes svårighetsgrad. ${ }^{27} \mathrm{I}$ bestämmelsen görs inte någon skillnad mellan brott av olika grovhetsgrad. Detta innebär t ex att domstolen primärt skall tillämpa samma straffskala för ett lindrigt bedrägeri, ett bedrägeri 
av "normal" grovhet och ett mycket grovt bedrägeri. En lagstiftningsteknik som denna lämnar ett mycket stort utrymme för domstolens prövning (eller ett utrymme som är så stort att det t o $\mathrm{m}$ kan leda till godtycke) och strider därför mot de principer som i dag allmänt accepteras i den nationella strafflagstiftningen. ${ }^{28}$ Möjligheten för domstolen att fastställa bötesstraffet "up to one million ECUs, which may be raised to five times the amount involved in the offence", utan att ange när detta skall ske och hur "the amount involved in the offence" skall fastställas lämnar också utrymme för ett godtycke som är så stort att det strider mot allmänt vedertagna principer för rättssäkerhet.

I praktiken innebär bestämmelsen i artikel 9 också en klar uppkriminalisering av vissa brott (men även en viss nedkriminalisering av andra). Straffnivån i Corpus Juris är överlag betydligt högre än den som är allmän i Norden. Bestämmelsen i artikel 9 leder till underliga undantag från en enhetlig strafflagstiftning inom en nation. Som exempel kan nämnas att en finsk tjänsteman som uppsåtligen och obehörigen röjer en tjänstehemlighet enligt finsk lag kan dömas till högst 2 år fängelse (SL 40:5). Om samma tjänsteman röjer en hemlighet under sådana omständigfheter att Corpus Juris' artikel 6 kan tillämpas blir straffet fängelse i högst 5 år, och därtill möjligen i kombination med ett betydande bötesstraff. Sådana motstridigheter inom samma stats straffsystem kan inte accepteras. Den avstämning mellan den nationella bestämmelsen (SL 40:5) och Corpus Juris' motsvarande bestämmelse som krävs för en harmonisering skall uppenbart ske kompromisslöst genom ett accepterande av Corpus Juris' straffnivå. Det är uppenbart att detta innebär en betydande påtvingad straffskärpning.

Corpus Juris' förslag till bestämmelse om straffmätning finns i artikel 15. Bestämmelsen fastställer till att börja med kravet på proportionalitet mellan brott och straff: "The penalties are to be imposed in accordance with the seriousness of the act, the fault of the offender and the extent of his participation in the offence.' Till denna del svarar bestämmelsen väl mot den ideologi och de principer som i dag är förhärskande i Norden. Men bestämmelsen innehåller också en precisering: "In particular the previous life of the accused, any previous offences, his character, his motives, his economic and social situation, and his efforts to make amends for the damage caused will be taken into account."

Denna tilläggsbestämmelse väcker förundran. För det första gäller den enbart straffmätningen för ett brott som begåtts av en fysisk person; någon motsvarande bestämmelse som gäller straffmätningen för ett brott som en juridisk person ansvarar för finns inte i Corpus Juris, trots att förslaget annars slår ett slag för ett korporativt ansvar. Men ännu mer förundrande är det att tilläggsbestämmelsen klart tar avstånd från det som i första hand förefaller vara huvudregeln. Straffet skall inte heller, såsom huvudregeln anger, bestämmas utgående från brottets straffvärde, men utgående från brottslingens personliga egenskaper, karaktär, sociala situation, handlande efter brottet etc. Till denna del är Corpus Juris inte i konformitet med gällande ideologi i Norden, och knappast heller med den princip om proportionalitet mellan konkret gärning och straff som förslaget sägs bygga på.

Det är skäl att notera att Corpus Juris inte innehåller några bestämmelser som gäller t ex villkorligt straffeller villkorlig frigivning från straffanstalt. I dessa avseenden kommer därför de nationella olikheterna att bestå. Något förenhetligande, eller ens en viss harmoni- 
sering, av de konkreta straffen i olika EU-stater kommer därför inte att genomföras genom Corpus Juris.

\section{KRITIK MOT CORPUS JURIS' PROCESSRÄTTSLIGA BESTÄMMELSER}

De principer som Corpus Juris processrättsliga bestämmelser bygger på är inte lika hävdvunna som de som ligger till grund för förslagets straffrättsliga del. Vissa av principerna är nyskapelser. I själva verket är inte alla "principer" som i förslaget kallas för principer, principer i en rättsdogmatisk bemärkelse, utan politiska markeringar eller slagord.

Bedömt ur ett nordiskt perspektiv är Corpus Juris' processrättsliga bestämmelser långt mer problematiska än de straffrättsliga bestämmelserna. Detta kan självfallet förklaras utgående från det faktum att straffprocessrätten inom EUs medlemsstater är långt mer heterogen än straffrätten. I själva verket är det mycket svårt att tala om en "europeisk straffprocessrätt", så snart man lämnar den gemensamma bas som består i en respekt för grundläggande mänskliga rättigheter.

Då det gäller de straffiprocessuella bestämmelserna finns det betydande olikheter också mellan de nordiska staterna. ${ }^{29}$ Det finns inte möjligheter att göra en detaljerad rättsjämförelse i detta sammanhang. Jag måste nöja mig med att ange vissa likheter och vissa gemensamma synsätt som är av betydelse för bedömningen av de förslag som ingår i Corpus Juris.

I fråga om brottmålsdomstolarnas organisation och sammansättning är den förhärskande bilden i Norden ganska enhetlig. Det finns en klar favorisering av domstolar med en allmän kompetens i jämförelse med domstolar med en begränsad specialbehörighet. Handläggningen av ekonomiska brott ankommer därför på de allmänna domstolarna och inte på specialdomstolar. Ett visst undantag i detta avseende utgjorde försöket med ekodomstolar i Sverige. Detta försök utföll emellertid inte positivt. ${ }^{30}$

Vid de allmänna domstolarna i Norden finns det i stor utsträckning också lekmän som domare. Av historiska, politiska och sociala skäl har det ansetts viktigt att också lekmän deltar i straffrättsskipningen. I Finland och i Sverige deltar lekmännen i brottmålsrättegången som domare på lika villkor med de juridiskt utbildade domarna i alla "vanliga" brottmål i första instans (tingsrätt) och i Sverige också i andra instans (hovrätt) ${ }^{31}$. Den kritik som funnits mot detta system har inte på allvar ifrågasatt den stora betydelsen av att ha lekmän som domare. ${ }^{32}$

I de nordiska länderna är ett system med rannsakningsdomare helt okänt. Vid en genomgång av den straffprocessrättsliga litteraturen under de senaste åren har jag inte funnit några uttryckliga förslag om införandet av ett rannsakningsdomarsystem. Ett sådant system måste därför bedömas vara helt främmande för den nordiska straffprocessrätten.

Däremot har den allmänna åklagaren ofta stora maktbefogenheter i de nordiska ländernas straffprocess. Som exempel kan nämnas Sverige, där den allmänna åklagaren har tre skilda roller. Åklagaren är förundersökningsledare då det gäller utredningen av de flesta brott. Det betyder att åklagaren under denna del av rättegången i visst avseende är arbetsledare för polisen. Åklagaren fattar beslut om väckande av åtal och han driver åtalet under själva rättegången. Åklagaren har också fătt en utökad roll som “domare" 
med rätt både att ge strafförelägganden och att besluta om att åtal inte skall väckas, trots att det finns tillräckliga bevis för den misstänktes skuld..$^{33}$

Åklagaren har också stora befogenheter att självständigt besluta om tvångsmedel. I Sverige kan åklagaren t ex i de allra flesta fall besluta att husrannsakan skall företas, utan ett särskilt förordnande av en domstol. ${ }^{34}$

Det bör emellertid samtidigt noteras att inställningen till möjligheten att använda olika typer av moderna spaningsmetoder har varit restriktiv i Norden. Detta har bl a inneburit att stränga materiella villkor har uppställts som en förutsättning tex för telefonavlyssning. Som ett exempel kan åter nämnas Sverige. Det är inte tillåtet att använda telefonavlyssning för andra brott än sådana där straffminimum är lägst två år fängelse. Inget av de brott som kriminaliseras i Corpus Juris artikel 1 till 8 kan i detta nu berättiga till telefonavlyssning enligt svensk lag. Artikel $20 \mathrm{i}$ Corpus Juris, som tillåter telefonavlyssning vid misstanke som gäller alla de nämnda brotten, måste därför uppfattas som ett mycket betydande ingrepp i enskild sfär i jämförelse med den rådande situationen.

Ifråga om principerna för åtal finns det en traditionell tudelning mellan Norge och Danmark å ena sidan och Finland och Sverige å den andra. ${ }^{35}$ Opportunitetsprincipen har varit den förhärskande principen i Danmark och i Norge, medan legalitetsprincipen har gällt i Sverige och i Finland. Under de senaste decennierna har denna skillnad utjämnats, framför allt på grund av att åtalseftergift blivit möjligt i Sverige och i Finland i många sådana fall då åklagaren tidigare var tvungen att väcka åtal. Utvecklingen i Sverige och Finland har till denna del stått i fullkomlig konformitet med den rekommendation som Europarådet antog år 1987 (R 87) 18. Flera goda skäl för en mer flexibel åtalsprövning har anförts både i doktrin och i statliga utredningar under de senaste decennierna. ${ }^{36}$

Då det gäller bevisning och bevisprövning bygger de nordiska ländernas processlagar på principen om en fri bevisning och en fri bevisprövning. Undantagen från denna huvudregel har varit få och begränsade. ${ }^{37}$

Ifråga om det internationella samarbetet mellan de nordiska länderna utformades redan på 1960-talet och 1970-talet ett unikt system. De viktigaste kännetecknen för detta system är en respekt för vissa nationella olikheter kombinerat med ett krav på effektivitet. Samarbetet bygger på de traditionella formerna för internationell rättshjälp. Det är möjligt att överföra lagföringen för ett brott från en nordisk stat till en annan, det är möjligt att utlämna en misstänkt person från ett nordiskt land till ett annat också om kravet på dubbel straffbarhet inte är uppfyllt och också om den misstänkte är medborgare i den stat som mottagit utlämningsbegäran, det är möjligt att ge handräckning i form av delgivning av nödvändinga handlingar, bevisupptagning etc. $i$ en annan nordisk stat än den där rättegången genomförs och det är möjligt att överföra verkställigheten av straff från en nordisk stat till en annan, inte bara då straffet är fängelse utan också då det är t ex böter eller en konfiskationspåföljd. ${ }^{38}$ Detta samarbete sker vanligen direkt mellan den behöriga nationella myndigheterna, utan användning av diplomatiska kanaler eller centrala judiciella myndigheter.

Erfarenheterna av samarbetet har varit goda. I den nordiska juridiska litteraturen finns knappast några exempel på samarbetsproblem mellan de nordiska staternas judiciella myndigheter som skulle förutsätta en annorlunda lösning. 
Förslagen i Corpus Juris avviker i flera väsentliga avseenden från det som kan kallas en "nordisk lösning".

Då det gäller domstolsorganisationen och domstolarnas sammansättning förespråkar förslaget domstolar som är specialicerade på ekonomiska brott och på domstolar som är sammansatta bara av yrkesdomare.$^{39}$ Att förespråka specialdomstolar för en viss kategori av brott hör till undantagen i den nordiska rättskulturen och att utesluta lekmannadomare från denna typ av mål strider klart mot den ordning som accepterats, kanske mest markant i Finland och i Sverige. Att begränsa åklagarnas behörighet då det gäller t ex beslut om användningen av tvångsmedel är en reform som väl kan förespråkas utgående från allmänna processrättsliga principer. Däremot finns det knappast några allmänt accepterade skäl för att införa en form av förundersökningsdomare med ett verksamhetsområde som faller mellan den allmänna åklagarens och den eljest behöriga domstolens. ${ }^{40}$ För de nordiska rättssystemen är detta ett främmande, processekonomiskt betungande och därför oönskat inslag.

Corpus Juris tar mycket klart avstånd från opportunitetsprincipen då det gäller väckande av åtal, ${ }^{41}$ och också från andra former för uppgörelser mellan den brottsmisstänkte och åklagarmyndigheten. I dessa avseenden står Corpus Juris' förslag i klar strid mot den tendens till utvidgning av åklagarens fria prövning då det gäller att väcka åtal. Varför Corpus Juris i detta fall valt en linje som står i direkt strid mot Europarådets rekommendation från år 1987 har inte motiverats på ett sätt som uppfyller minimikraven för rättspolitisk debatt. Förslaget står också i strid mot de strävanden som finns för en förstärkning av möjligheterna till frivilliga uppgörelser mellan brottslingen, offret och samfundet.

Den största avvikelsen från gällande tradition ligger emellertid i Corpus Juris' förslag om attetablera en jurisdiktion som omfattar hela det "europeiska territoriet" och grunda en central europeisk åklagarmyndighet, med en behörighet som omfattar alla EU-stater. I förslaget motiveras detta med kravet på effektivitet, kravet på att i detta skede kraftfullt demonstrera att det inte finns tecken på en politisk stagnation då det gäller att bekämpa ekonomiska brott som riktas mot EU och kravet på att åstadkomma ett enkelt juridiskt system som omfattar hela $\mathrm{EU}^{42}$

Skälen till förslaget kan intuitivt förefalla goda. Skälen sammanfattas i förslaget på följande sätt:

\footnotetext{
"These rules will allow long, complex procedures of bilateral cooperation to be avoided; procedures all the more inefficient in that crime of this kind is very frequently multinational. International letters rogatory would also become unnecessary between Member States of the European Union, and similarly extradition, also rendered obsolete by the institution of the EPP."
}

Det konstateras också att förslaget innebär att den ojämlighet som nu finns mellan brottslingar och brottskontrollörer; på grund av att kontrollörerna är bundna av existerande gränser, medan brottslingarna inte är det, försvinner.

En närmare analys av förslaget väcker dock starka tvivel. Ett av argumenten för att helt 
överge de traditionella formerna för internationell rättshälp är attEU:s medlemsstater inte visat tillräcklig vilja att snabbt implementera bestämmelserna i de centrala internationella konventionerna i den nationella rätten. ${ }^{43}$ Detta kan i och för sig också vara riktigt. Den väsentliga frågan är emellertid vilken politisk vilja det finns i medlemsstaterna att acceptera den mer långtgående Corpus Juris och bidra till dess realisering.

Corpus Juris-förslaget undervärderar också de svårigheter som förmodligen uppstår i praktiken för en "European public prosecution service" att genomföra sina uppgifter inom det enhetliga europeiska territoriet. Det är självklart att väsentliga delar av efterforskningen också i fortsättningen måste ske nationellt, av denationella polismyndigheterna och de andra brottskontrollerande myndigheterna. I detta avseende har EPP (the European Public Prosecutor) inte några fördelar framom en nationell åklagare eller en annan nationell myndighet. Förslaget förbigår också alla de svårigheter som kan uppstå i samband med säkerställandet av den brottsmisstänktes rätt till försvar. Hur skall man t ex säkerställa att den brottsmisstänkte har möjligheter att åtnjuta hjälp av den försvarsadvokat som han önskar anlita, då brottmålsrättegången och de rättsliga konsekvenserna av den splittras på flera stater.

Den starkaste kritiken mot förslaget är emellertid att det, åtminstone till en början, skapar två "nationella" straffsystem och $t v a$ "nationella" processordningar.

I ett nationellt sammanhang är Corpus Juris en specialstrafflag vid sidan om den allmänna strafflagen och en specialstraffprocesslag vid sidan om den allmänna processlagen. De brottsutredande myndigheterna, domarna och domstolsförfarandet avviker då det gäller handläggningen av brott mot Corpus Juris på många väsentliga punkter från det som gäller i brottmålsprocessen $\mathrm{i}$ allmänhet. Den europeiska centrala åklagarmyndigheten (EPP) har en specialbehörighet som är ganska begränsad; han har ju inte möjligheter att befatta sig med andra brott än dem som regleras i Corpus Juris.

En brottsling är däremot sällan i praktiken så begränsad. Det sannolika är att en person i framtiden ofta kommer att begå en serie brott av vilka bara en del är av den typ som regleras i Corpus Juris. Alla andra är nationella brott. T ex är korruption som gällt en nationell myndighet ett nationell brott under den nationella strafflagen, medan korruption som gällt en myndighet med befogenhet att fatta EU-beslut är ett brott under Corpus Juris. Det sistnämnda, men inte det förra, skall därför efterforskas och handläggas i den ordning som Corpus Juris förutsätter. En förnuftig utredning och lagföring av brotten förutsätter emellertid att samma myndigheter och samma domstol handlägger det hela med stöd av samma enhetliga bestämmelser. Om Corpus Juris realiseras blir detta inte möjligt.

I själva verket kan man säga att Corpus Juris kanske eliminerar vissa av de svårigheter som finns när det gäller myndighetssamarbete över gränserna, men skapar nya inom gränserna for samma stat.

\section{KONKLUSION}

Vid ett nordiskt seminarium om det straffrättsliga skyddet av EUs finanisella intressen som arrangerades i Uppsala i november 1996, ${ }^{44}$ där också Corpus Juris- förslaget behandlades, kom de närvarande (forskare och parktiker) till följande konklusion: 
"Although the aims of the proposal are commendable the approach chosen is not likely to result in greater efficiency than a less ambitious scheme of establishing specialized national agencies and reforming the law of international legal assistance. The proposal might be counterproductive.in that it can draw the attention away from politically more attractive programmes."

Denna konklusion anser jag vara god och berättigad. I ett nordiskt perspektiv förefaller det t ex vara nödvändigt att satsa betydligt mer på en situationell brottsprevention också då det gäller ekonomiska brott som riktas mot EU. Att med centraliserat tvång försöka förenhetliga straffrätten och straffprocessrätten inom EU skapar inte det förtroendemellan staterna och mellan staternas myndigheter som förutsätts för gemensamma aktioner mot brottslighet. Av egen erfarenhet vet vi att den nordiska straffrättsliga gemenskapen inte är ett resultat av gemensam lagstiftning, utan att lagstiftningen är ett resultat av ömsesidigt förtroende och långvarig politisk gemenskap.

Adress: Professor Per Ole Träskman.

Juridiska fakulteten vid Lunds universitet.

Box 207, S- 22100 Lund.

E-post: Per_Ole.Traskman @jur.lu.se

\section{Noter:}

1 Se Vagn Greve: Forholdet mellem EU-strafferet og national strafferet. NTfK 1994, s. 231-243.

2 Förslaget har bl a publicerats i den tvåspråkiga (engelska och franska) skriften "Corpus Juris portant disposition pénales pour la protection des intérêts financiers de l'Union européennne"/"Corpus Juris introducing penal provisions for the purpose of the financial interests of the European Union" sous la direction de Mireille Delmas-Marty. Direction Générale du Contrôle Financier, 1997. De flesta hänvisningar i fortsättningen till Corpus Juris avser denna skrift. En svensk översättning har utgetts av Nils Jareborg, Uppsala 1997. Arbetsgruppen bakom förslaget bestod av professorerna Enrique Bacigalupo (Madrid), Mireille Delmas-Marty (Paris), Giovanni Grasso (Catania), Nils Jareborg (Uppsala), John R. Spencer (Cambridge), Dionysios Spinellis (Aten), Klaus Tiedemann (Freiburg im Breisgau) och Christine van den Wyngaert (Antwerpen). Den nordiska företrädaren, Nils Jareborg, har i den svenska utgåvan (s. 2) frånsagt sig allt ansvar för det slutliga förslaget: "Min (efterföljande) medverkan till tillkomsten av Corpus juris har inte varit av den arten att jag på någon punkt anser mig ansvarig för dess innehåll."

3 Detta fastslås bl a i Corpus Juris s. 40 .

4 Corpus Juris s. 40:"From the preceding analysis, it is clear that assimilation guarantees neither efficiency, nor justice providing equal treatment for all economic operators; that cooperation, designed in order to increase efficiency, leads unavoidable to greater complexity; and finally that harmonisation aimed at strengthening justice and 
efficiency, contributes to the complexity of the whole. From this we decided that the only way jo join together the three qualities -justice, simplicity and efficiency - is by unification."

5. Min granskning är kritisk, men kritikens syfte är att vara konstruktiv. Jag avvisar alltså inte ändringsförslagen i Corpus Juris bara för att de innebär ändringar av "gällande rätt". En sådan kritik skulle i själva verket vara omöjlig på grund av att "gällande rätt" inte har ett identiskt innehåll i de nordiska länderna. Min kritik bygger på att förslagen i Corpus Juris grundas på en ideologi eller på andra grundläggande principiella ställningstaganden som avviker från dem som vi i Norden allmänt har accepterat som de riktiga.

${ }^{6}$ Se Corpus Juris s. 14

7 Under några år verkade en särskild forskningsorganisation, European Documentation \& Research Network on cross-border crime (EDRN), med syfte att genomföra och understöda empirisk forskning om brott som drabbar EUs finanisella intressen. Organisationen hade formen av en fond och den erhöll medel för sin verksamhet ur EUs budget, genom förmedling av kommissionen. De viktigaste forskningsprojekten som genomfördes inom denna ram var de som gällde EU-bedrägerier ("Eurofraud") under ledning av professor Ulrich Sieber (Würtzburg). Efter konflikter mellan fondens ledning och kommissionen om vilken inriktning forskningen skulle ha, upphörde verksamheten och fonden upplöstes 1996.

8 Se också Per Ole Träskman: Mullvardens öga och synen på kriminalpolitiken. Lundaforskare föreläser, årg. 28, s. 7-15.

9 Per Ole Träskman: The Dragons Egg-Drugs-related Crime Control. I boken Beware of Punishment. On the Utility and Futility of Criminal Law. Scandinavian Studies in Criminology. Vol. 14 edited by Annika Snare. Oslo 1995, s. 158-159.

${ }^{10}$ Vagn Greve: Forholdet mellem EU-strafferet og national strafferet. I Dag Victor (red.):Varning för straff. Om vådan av den nyttiga straffiätten. Stockholm 1995, s. 179.

${ }^{11}$ Se Corpus Juris, s.40.

${ }^{12}$ Se också Nils Jareborg:Vilken sorts straffrätt vill vi ha -Om defensiv och offensiv straffrättspolitik. I Dag Victor (red.):Varning för straff. Om vådan av den nyttiga straffrätten. Stockholm 1995, s. 19-27.

${ }^{13} \mathrm{Om}$ legalitetsprincipens betydelse och innebörd se framför allt Dan Frände: Den straffrättsliga legalitetsprincipen. Ekenäs 1989.

${ }^{14}$ Ett visst objektivt ansvar är visserligen känt bl a i dansk strafflagstiftning. Se Vagn Greve \& Lars Bo Langsted: Hovedlinier i erhvervsstrafferetten. 4. udgave, København 1996, s. 62-64. En sådan form för straffrättsligt ansvar är emellertid kontroversiell och ofta kritiserad.

${ }^{15} \mathrm{Se}$ bl a bestämmelsen i den finska strafflagen, SL 6:1 som har följande lydelse: Vid straffmätning skall samtliga på saken inverkande straffskärpande och strafflindrande grunder samt enhetligheten i straffpraxis beaktas. Straffet skall utmätas så, att det står i rättvist förhållande till brottets skadlighet och farlighet samt till den skuld gärningsmannen ådagalagt i brottet. Se också det nordiska betänkandet NU 1984:2, Straffutmåling. 
${ }^{16}$ Se det nordiska betänkandet NU 1986:2, Företagsböter, som innehåller en numera något föråldrad beskrivning, samt de senare tillkomna bestämmelserna i den finska strafflagen, kap. 9.

${ }^{17}$ Bestämmelsen (art. 14) har följande lydelse: (1)The offences defined above in Articles 1-8 above may be committed by corporations, and also by other organisations which are recognised by law as competent to hold property in their own name, provided the offence is committed for the benefit of the organisation by some organ or representative of the organisation, or any person acting in his name and having power, whether by law or merely in fact, to make decisions. (2) Where it arises, the criminal liability of an organisation does not exclude that of any natural person as author, inciter or accomplice to the same offence.

${ }^{18}$ Dessa gärningar är: oredlighet avseende bidrag eller avgift, oredlighet vid upphandling, korruption, missbruk av behörighet, trolöshet mot huvudman, brott mot tystnadsplikt, penningtvätt och häleri, stämpling.

${ }^{19}$ Se SOU 1996:185, Straffansvarets gränser. Del II. Bilagor, s. 207-210.

${ }^{20}$ En god jämförande översikt över olika lösningar finns i betänkandet SOU 1996:185 (se fotnot 19), Del II, s. 13-102.

${ }^{21}$ Se det finska kommittébetänkandet Kom bet 1976:72 Straffrättskommitténs betänkande. Band I, s. 44-45. Se också Per Ole Johansen: Alternative sanksjoner mot økonomisk kriminalitet. Ståle Eskeland \& Einar Høgetveit (red.): Økonomiske forbrydelser og straff - juridiske grunnlagsproblemer. Oslo 1994, s.46-49.

${ }^{22}$ Se också Per Ole Johansen a.a., s. 51-57.

${ }^{23}$ Det är inte heller klart vilka dessa myndigheter skall vara. För vissa av de möjliga myndigheterna är en roll som straffrättslig kontrollör främmande, medan andra myndigheter saknar den ekonomiska sakkunskap som övervakningen kan förutsätta. Jfr den diskussion som har förts då det gäller revisorns kontroll av ekonomisk brottslighet och de egentliga miljömyndigheternas kontroll av miljöbrottslighet.

${ }^{24}$ Det kan emellertid konstateras att övervakning av bolaget etc används som en straffrättslig sanktion både i vissa delar av USA och i vissa europeiska stater, t ex Nederländerna.

${ }^{25}$ Se t ex den finska strafflagen, SL 2:10 och den danska strafflagen, strfl $\S 78$ och 79. Se också Vagn Greve: Straffene. København 1996, s. 196-199.

${ }^{26}$ Bestämmelsen lyder: (1) The principal penalties, common to all offences set out in Articles 1 to 8, are as follows: a) for natural persons, a custodial sentence for a maximum of five years and/or a fine of up to one million ECUs, which may be raised to five times the amount involved in the offence; $b$ ) for organisations, legal supervision for a maximim of five years and/or a fine of up to one million ECUs, which may be raised five times the amount involved in the offence; c) confiscation of the instruments, fruits and profits of the offence; d) publication of the conviction.

Artikeln (stycke 2) innehåller därtill bestämmelser om vissa tilläggsstraff, bl a "exclusion fiom future subsidies" och "ban from Community and national public office".

${ }^{27}$ Se närmare Andrew von Hirsch: Past or Future Crimes: Deservedness and Dan- 
gerousness in the Sentencing of Criminals. New Jersey 1985, Chapter IV

${ }^{28}$ Se Tapio Lappi-Seppälä: Rangaistuksen määräämisestä I. Teoria ja yleinen osa. Vammala 1987, särskillt s. 637-654.

${ }^{29}$ En viss (delvis föråldrad) jämförelse mellan de nordiska ländernas straffprocessuella system finns i P.O. Träskman: La phase décisoire du procès pénal en droit comparé: Le systme des pays nordiques. RIDP 1986, s. 736-771, och La phase exécutoire du procès pénal. Le droit de pays nordiques. RIDP 1990, s. 709-744.

${ }^{30}$ Se Hans-Gunnar Axberger: Eko-brott, Eko-lagar och Eko-domstolar. En rättspolitisk utvärdering av lagstiftningen mot ekonomisk brottslighet. Brå-forskning. Stockholm 1988, och densamme: Det våras för kampen mot ekonomisk brottslighet. Brå-Apropå 2-3/94, s. 8-15.

${ }^{31}$ Se svenska RB 1:3b och 4:1 samt finska RB 2:1.

${ }^{32}$ Se Christian Diesen: Lekmän som domare. Stockholm 1996, s. 376-383.

${ }^{33}$ Se Ulla Jacobsson: Lagbok i straffprocess. Malmö 1996, s. 53-61.

${ }^{34}$ Tbidem, s. 184-194.

${ }^{35}$ Se tex P.O.Träskman: Åtalsrätt. De offentliga åklagarna, deras behörighet och uppgifter enligt gällande finsk rätt. Helsingfors 1980, s. 117-200.

${ }^{36}$ Se Petri Jääskeläinen: Syyttäjä tuomarina. Vammala 1997, s. 74-224.

${ }^{37}$ Se Lauri Hormia: Todistamiskielloista rikosprosessissa I. Oikeudellinen tutkimus. Vammala 1978, samt II, Vammala 1979.

${ }^{38}$ Se Nils Jareborg och Petter Asp (utg.): Svensk internationell straffprocessrätt. Uppsala 1995.

${ }^{39}$ Se Corpus Juris artikel 26 (1), som har följande lydelse:'The offences set out above (Articles 1 to 8 ) are tried by national, independent and impartial courts, appointed by each Member State according to the rules on competence ratione materiae of the national law, sitting at the centres where the EDelPP is based. The courts must consist of professional judges, specialising wherever possible in economic and financial matters, and not simple jurors or lay magistrates."

${ }^{40}$ Det kan visserligen hävdas att den frihetsdomare ("juge de libertè") som Corpus Juris förutsätter inte är en rannsakningsdomare med alla de funktioner som sådana domare har t ex i Frankrike. Frihetsdomaren är emellertid en underlig särdomare som enligt Corpus Juris-förslaget skall överta vissa av de funktioner som i detta nu innehas av den allmänna åklagaren och vissa av dem som (den ordinära) underrättsdomaren har.

${ }^{41}$ Se Corpus Juris artikel 19(4) som lyder:'’The decision to prosecute, which means opening an investigation, may be taken by the EPP whatever sum of the fraud involved. TheEPP, bound by the legality principle, must bring a prosecution if it appears that one of the offences (Articles 1 to 8 ) has been committed. It may however, by a decision with special grounds communicated immediately to the person who has informed it, or denounced it to its officials or laid a complaint: a) either refer offences which are not serious or which affect principally national interests to the national authorities; b) or drop the case, if the accused, having admitted guilt, has made amends for the damage caused and, as the case may be, returned funds received illegally ..."

${ }^{42} \mathrm{Se}$ Corpus Juris s.18-42 
${ }^{43}$ Corpus Juris s. 20. Det framgår inte klart hur man har tänkt sig att Corpus Juris skall bli realiserat. Det naturliga förefaller vara en konvention, men detta har knappast varit den avsikt som de drivande bakom projektet har haft. Det förefaller snarare som om de har tänkt sig att bestämmelserna skall intas i en förordning. Se också Marie-Aimée Gaspari: Quelle base juridique pour le Corpus Juris. Agon 1997(15), s. 4-6.

${ }^{44}$ Se också Seminar on the Protection of the European Communities' Financial Interests. Agon 1997(14), s. 18-19.

*Denna artikel utgör en bearbetad version av ett inledningsanförande (på engelska) vid ett seminarium arrangerat $i$ Helsingfors i juni 1997. Inledningsanförandets titel var "Is there any space for the Nordic Legal Tradition in the Project concerning a Common European Legal Space?" 